\title{
Trends in the profile of blood donors at a large blood center in the city of São Paulo, Brazil
}

\author{
Thelma Gonçalez, ${ }^{1}$ Ester C. Sabino, ${ }^{1}$ and Dalton F. Chamone ${ }^{1,2}$
}

ABSTRACT Objective. To describe the trends in the profile of blood donors from 1995 through 2001 at a large blood center in the city of São Paulo, Brazil, particularly following the initiation in 1998 of marketing strategies aimed at substituting replacement donors with altruistic repeat donors.

Methods. Using an information system that had been established at the Pro-Blood Foundation/Blood Center of São Paulo (Fundação Pró-Sangue/Hemocentro de São Paulo) in 1994, we collected information on sex, age, and type of donation for the years 1995-2001. We classified blood donors as either replacement blood donors (if they stated that the reason for donating was that they had a friend or relative in the hospital) or as altruistic donors. First-time blood donors were those who had not donated in our institution since the establishment of the information system.

Results. The percentage of repeat altruistic blood donors increased over time as first-time replacement donors declined for both genders. The proportion of altruistic donors climbed from $20 \%$ of all blood donors in 1995 to 57\% in 2001. In 2001, first-time blood donors represented only $52 \%$ of all donors, as contrasted to $88 \%$ in 1995 . Female donors increased from $20 \%$ to $37 \%$ of the donors over the period studied.

Conclusions. Our data provide evidence that the São Paulo population has responded well to the marketing strategies that have been introduced in our institution. We believe that similar promotional efforts elsewhere in Brazil would produce comparable, positive results.

Key words Blood banks, blood donors, social marketing, Brazil.

Until 1980 in Brazil, blood for transfusion was primarily collected at private blood centers, with paid dona-

\footnotetext{
1 Fundação Pró-Sangue/Hemocentro de São Paulo, São Paulo, São Paulo, Brasil. Send correspondence to: Ester C. Sabino, Fundação Pró-Sangue/ Hemocentro de São Paulo, Av Dr Enéas de Carvalho Aguiar 155, 1 andar, São Paulo, SP, Brasil 05403-000; fax: 5511 30888317; e-mail: sabinoec@ uol.com.br

2 Faculdade de Medicina da Universidade de São Paulo, Departamento de Hematologia e Hemoterapia, São Paulo, São Paulo, Brasil.
}

tions being common. In addition, the country had no national law regulating blood bank operations (1). However, with the onset of the AIDS epidemic, blood collection practices became an important political issue, and the Brazilian Ministry of Health initiated a program to develop an infrastructure for the supervision of blood banks. Public blood centers were created in all the states of Brazil, and, although they were under state administration, federal funds were made available to the centers. Over the following years, laws and technical recommendations were also promulgated (2).

One of the first laws mandated an end to paid blood donations. There were numerous problems with this new rule because the blood banks did not have expertise in recruiting voluntary blood donors, and there was a concern that the law would dramatically decrease the blood supply. The blood centers rapidly started a pro- 
gram to recruit donors from among friends and relatives of hospitalized patients. This procedure had a noticeable impact, making it possible to maintain the blood supply despite its sudden reduction due to the elimination of paid blood donors. These "replacement donors" became the major source of blood units in Brazil (2).

One of the main problems in relying on this type of donor is that most of them are first-time blood donors, so the prevalence of infectious diseases is very high, with a high percentage of discarded units $(3,4)$. During the 1990s, concerted efforts were made to change the blood donor supply from replacement first-time donors to repeat donors. In the scientific literature, there is little information on the demographic characteristics of blood donations in Brazil. In this article we describe the efforts to encourage donations by repeat donors and the dramatic changes that occurred during the period of 1995-2001 at the ProBlood Foundation/Blood Center of São Paulo (PBF/BCSP) (Fundação PróSangue/Hemocentro de São Paulo). Located in the city of São Paulo, the $\mathrm{PBF} / \mathrm{BCSP}$ is the largest blood center in Latin America. The PBF/BCSP collects around 200000 blood units per year, which represents some $50 \%$ of the blood collected in the city and almost $10 \%$ of all blood units in Brazil.

\section{MATERIALS AND METHODS}

In 1994, the PBF/BCSP introduced an information system to control all the steps involved in blood donation. All the PBF/BCSP blood donors were given a unique identification number after verification that they had made no prior donations in our institution. For the purpose of this study we considered first-time blood donors those individuals who were donating blood in our institution for the first time. We classified blood donors as replacement blood donors if they stated in their initial interview that they had a friend or relative in the hospital, and that that was their reason for coming to donate blood. If their donation was not targeted to a specific individual, the donation was classified as altruistic.

For our study, each donor was only counted one time per year, and all the donors were classified according to their first donation in that year. The data presented here generally represent the number of donors rather than donations (one figure does provide information on the total number of donations per year).

Before 1998, PBF/BCSP donor recruitment focused on friends and relatives of the hospitalized patients. Each patient was asked to have 20 potential blood donors come to a hospital collection center. In addition, each time a person would come to visit a patient, it was mandatory for that person to attend a lecture explaining the importance of blood donation. That continued until the quota of 20 potential blood donors was reached for that patient.

In July 1998, PBF/BCSP made the decision to ban this procedure. Although patients were still asked to try to persuade friends and relatives to come to donate, neither a specific donor number nor a lecture was mandatory. The focus of the PBF/BCSP recruitment program shifted to altruistic donation, with a number of marketing strategies and techniques being applied. A phone-marketing program was established. To supplement ongoing collections at hospital sites, there was an increase in the number of mobile, off-site blood collections, to such locations as companies, universities, military facilities, supermarkets, churches, and clubs. In a campaign called "Act Like Your Idol," television and music celebrities were invited to donate blood, and images of them making the donation were carried in the mass media. With the support of private marketing companies, television and radio campaigns were organized, using public service announcements. When blood stocks fell to a low level, radio and TV stations and newspapers reported that. A campaign directed toward women blood donors was also created. The hospital collec- tion sites were renovated to better accommodate the donors, and the staff was trained to improve the quality of their service, emphasizing courtesy throughout the donation process. Efforts were made to decrease the time that blood donors had to wait to donate as well as to improve the quality of the food and beverages offered to them after the donation.

To assess the impact that these marketing efforts and the other changes had on the profile of PBF/BCSP blood donors, we collected information on age, sex, and type of donation for the years 1995-2001. In the statistical analysis of these data, we performed the test for linear trend, using Epi Info version 6.4 computer software (Centers for Disease Control and Prevention, Atlanta, Georgia, United States of America).

\section{RESULTS}

From 1995 through 2001, a mean of some 193000 individuals per year donated blood. Because the interval of donations among repeat donors was near one year, the total number of donations was not much higher than the total number of blood donors (Figure 1). Some $50 \%$ of the blood donors were under 30 years old, with the age distribution remaining constant throughout the study period.

While the total number of donors per year remained about the same over the study period, their profile changed noticeably. For example, in 1995, the 36118 women who donated blood constituted $20 \%$ of the blood donors that year. In 2001, the 68850 women donors represented $37 \%$ of the total number of blood donors, an increase that was statistically significant $(P<0.01)$.

Figures 2 and 3 present, for men and women respectively, the evolution in donors, showing the trends in the numbers of first-time altruistic donors, repeat altruistic donors, first-time replacement donors, and repeat replacement donors. The proportion of repeat altruistic donors increased over the 
FIGURE 1. Trends in the age distribution of blood donors and in the total number of donors and of donations during 1995-2001 at the Pro-Blood Foundation/Blood Center of São Paulo, Brazil

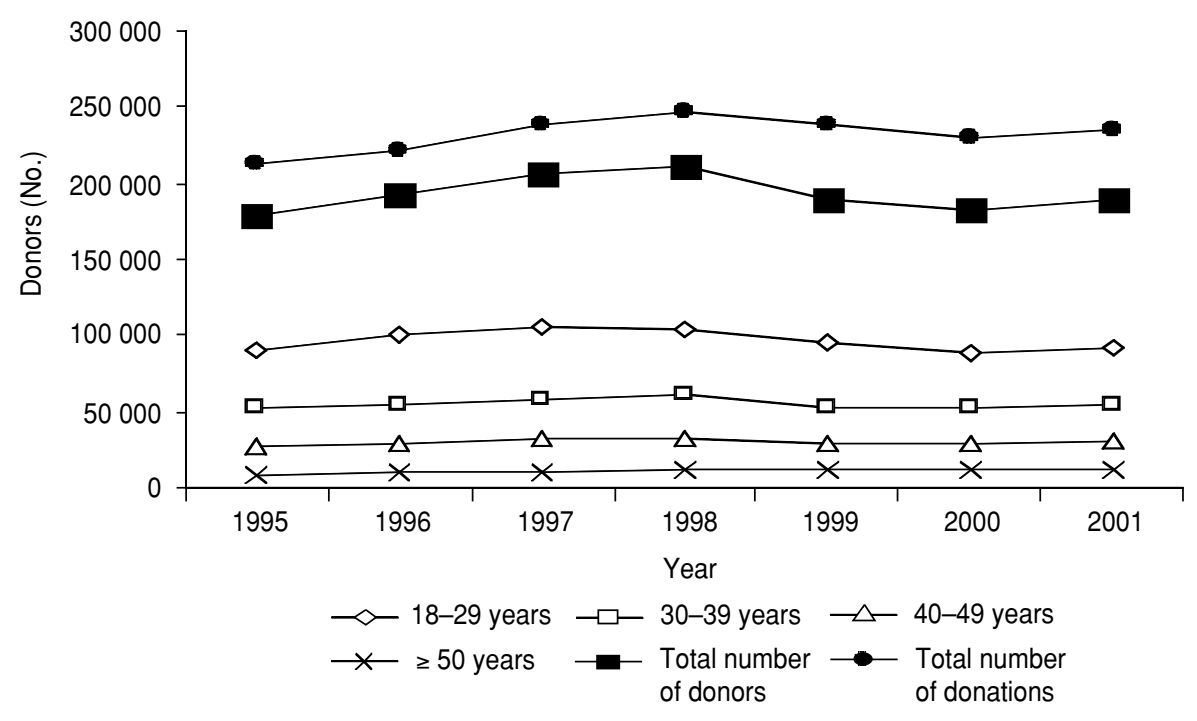

FIGURE 2. Trends in the number of male blood donors according to the type of donation during 1995-2001 at the Pro-Blood Foundation/Blood Center of São Paulo, Brazil

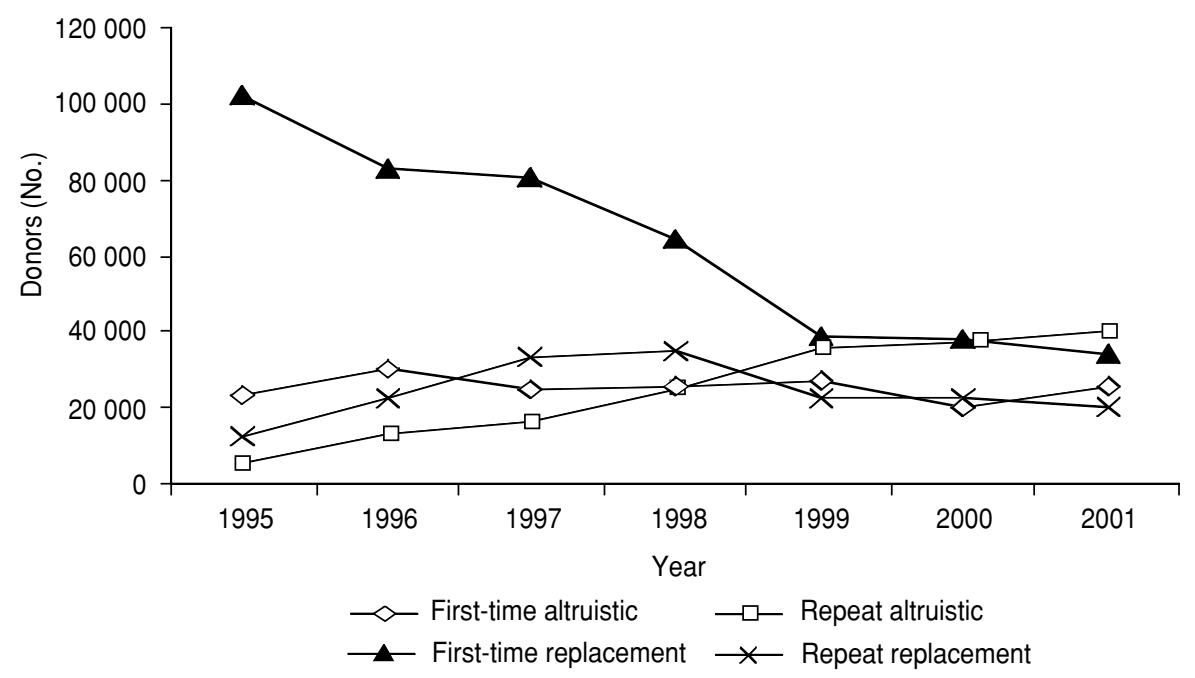

study period, and the proportion of first-time replacement donors declined, for both genders. Altruistic donors represented $20 \%$ of the total number of donors in 1995, while in 2001 they represented $57 \%(P<0.01)$. In 2001 first-time blood donors represented only $52 \%$ of the donors, a sig- nificant decrease from $88 \%$ in 1995 $(P<0.01)$.

\section{DISCUSSION}

The goal of any blood donation system is to have a stable, safe, and ade- quate blood supply. Continual monitoring of the demographics of the blood donor population of any community is required to identify problems in, and direct efforts towards, reaching this goal (5-9).

The data presented in this paper represent an attempt at analyzing the blood donor population in the city of São Paulo, by focusing on the PBF/ BCSP over the 1995-2001 period. These data depict the changes that occurred as a result of trying to substitute replacement donors with altruistic repeat donors. Following the start in 1998 of a more aggressive PBF/ BCSP program to increase altruistic donations, there was a dramatic change in the donor profile in our center over the following three-year period, with a sharp increase in female first-time and repeat altruistic donors and also male repeat altruistic donors. This shows that the population of our city has responded well to the marketing strategies that we have applied. We believe that a similar response would occur all over Brazil. That is because the city of São Paulo has a high percentage of migrants from other parts of the country and is thus culturally very similar to other large cities in Brazil.

This study highlights significant differences between the donor population in the city of São Paulo and the donor populations in the United States and Europe. The study also points to differences in the issues that a Brazilian blood bank must face in trying to build and maintain a viable blood supply. In contrast to the United States and Europe, blood donors in São Paulo are younger, with some $50 \%$ of them being under the age of 30 . This could be helpful for Brazil's blood supply if initiatives are pursued to retain these individuals as repeat donors over a long period of time. The PBF/ $\mathrm{BCSP}$ has been working to retain repeat donors by helping to organize an association of such donors.

The data presented here have shown that over the study period, first-time blood donors have been replaced by repeat blood donors in the PBF/BCSP. 
FIGURE 3. Trends in the number of female blood donors according to the type of donation during 1995-2001 at the Pro-Blood Foundation/Blood Center of São Paulo, Brazil

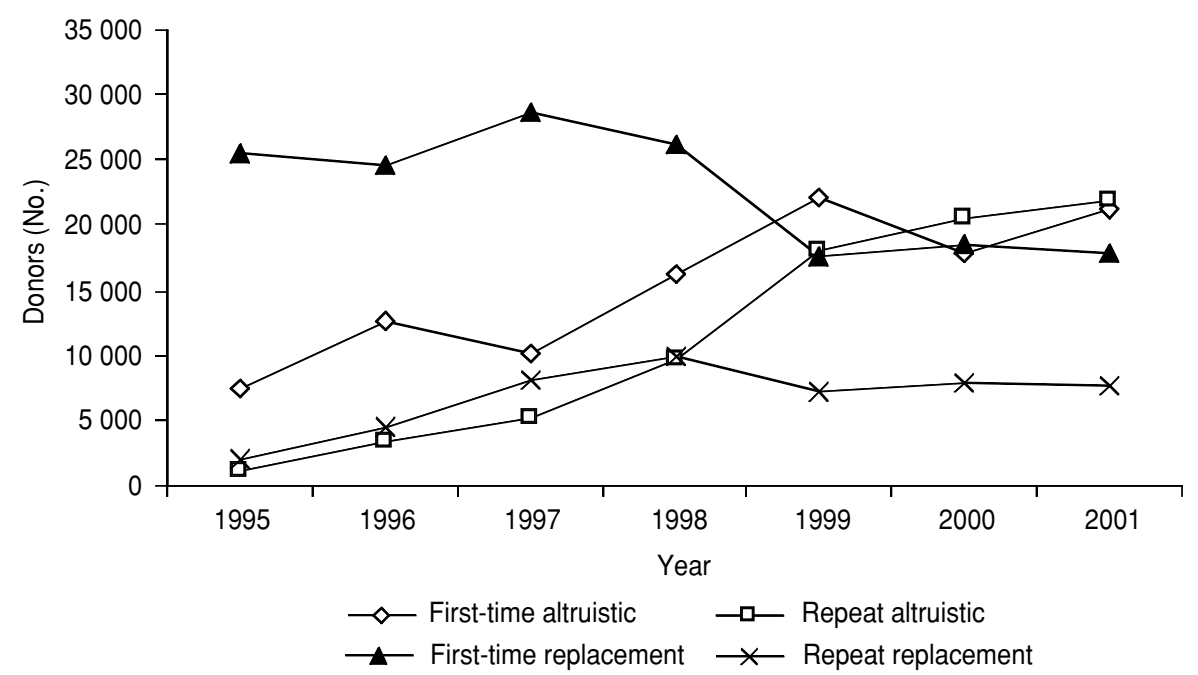

A partial explanation for this result might be that data collection was initiated in 1994, so that some of the donors we designated as first-time blood donors early in the 1995-2001 study period were actually repeat donors who had donated before 1994. However, this explanation does not fit all the changes that we observed. If that explanation were true, starting in 1998, repeat replacement donors should have increased, but the opposite happened. Also, this explanation certainly does not apply to the number of firsttime female altruistic donors, which generally increased over time.

This is the first study in Brazil to provide such detailed information on ongoing trends in blood donor profiles. More general data on blood donor characteristics in Brazil have been collected for the last several years by the National Health Surveillance Agency (NHSA) (Agência Nacional de Vigilância Sanitária, or ANVISA), a recently created federal agency that con- trols blood products in Brazil (10). According to the NHSA, in the year 2000 for Brazil as a whole, $52 \%$ of blood donations were from repeat donors, $23 \%$ of donations were from females, and $41 \%$ were altruistic donations.

Our figures and those from the NHSA indicate that there is still a long way to go in improving the Brazilian blood supply in comparison to that of the United States. In the latter, for example, first-time blood donors represent only $19 \%$ of the donor population, and the majority of donations are altruistic $(5,6)$. Nevertheless, our ongoing efforts have yielded significant improvements in the donor population of our center, as we have already indicated and as also demonstrated by a $50 \%$ decrease in the percentage of discarded blood units from 1995 to 2001 (3).

The results in our center suggest that a coordinated marketing effort is able to rapidly change blood donor profiles even in a population only accustomed to donating blood for a friend or relative, and also that the broader population of Brazil would likely respond well to similar promotional efforts.

Acknowledgments. The authors thank Dr. Allen Mayer for critical discussion and suggestions. This work was supported by the Fundação PróSangue/Hemocentro de São Paulo.

\section{REFERENCES}

1. Santos LAC, Moraes C, Coelho SPV. A hemoterapia no Brasil de 64 a 80. PHYSIS 1991; 1(1):161-181

2. Santos LAC, Moraes C, Coelho SPV. Os anos 80: a politização do sangue. PHYSIS 1992;2(1): 107-149.

3. Salles NA, Sabino EC, Barreto CC, Barreto AM, Otani MM, Chamone DF. Descarte de bolsas de sangue e prevalência de doenças infecciosas em doadores de sangue da Fundação Pró-Sangue/Hemocentro de São Paulo. Rev Panam Salud Publica 2003;13(2/3):111-116.

4. Mundee Y, Kamtorn N, Chaiyaphruk S, Nantachit N, Ness PM, Nelson KE. Infectious disease markers in blood donors in northern Thailand. Transfusion 1995;35(3):264-267.

5. Glynn SA, Schreiber GB, Busch MP, Kleinman $\mathrm{SH}$, Williams AE, Nass CC, et al. Demo- graphic characteristics, unreported risk behaviors, and the prevalence and incidence of viral infections: a comparison of apheresis and whole-blood donors. The Retrovirus Epidemiology Donor Study. Transfusion 1998; 38(4):350-358.

6. Glynn SA, Kleinman SH, Schreiber GB, Busch MP, Wright DJ, Smith JW, et al. Trends in incidence and prevalence of major transfusiontransmissible viral infections in US blood donors, 1991 to 1996. Retrovirus Epidemiology Donor Study (REDS). JAMA 2000;284(2): 229-235.

7. Liu TC, Kuperan P, Tan C, Lin TK, Lee SH. Structuring a safer donor-replacement program. Transfusion 1998;38(4):368-372.

8. Wu Y, Glynn SA, Schreiber GB, Wright DJ, Lo A, Murphy EL, et al. First-time blood donors: demographic trends. Transfusion 2001;41(3): 360-364.

9. Westphal RG. Donors and the United States blood supply. Transfusion 1997;37(2):237-241.

10. Brasil, Agência Nacional de Vigilância Sanitária. Serviços de hemoterapia - relatórios de produção. Available from: http://www.anvisa. gov.br/correlatos/sangue/hemoterapia/ producao.htm [Internet site]. Accessed 20 June 2002.

Manuscript received 19 July 2002. Revised version accepted for publication on 19 November 2002. 
RESUMEN Objetivo. Describir las tendencias observadas de 1995 a 2001 en el perfil de los donantes de sangre de un gran centro de hemoterapia en la ciudad de São Paulo, Brasil, particularmente después del lanzamiento en 1998 de estrategias de mercadeo orientadas a sustituir los donantes por reemplazo por donantes altruistas a repetición.

Tendencias en el perfil de los donantes de sangre de un gran homocentro de la ciudad de São Paulo, Brasil Métodos. Usando un sistema de información que había sido establecido en la Fundación Pro-Sangre/Hemocentro de São Paulo (Fundação Pró-Sangue/Hemocentro de São Paulo) en 1994, obtuvimos información acerca del sexo y la edad de los donantes y el tipo de donación para el período de 1995-2001. Clasificamos a los donantes de sangre en donantes de reemplazo (si su motivo para donar sangre era la presencia de un pariente $u$ amigo en el hospital) o bien en donantes altruistas. Las personas que donaban su sangre por primera vez fueron aquellas que nunca habían donado sangre en nuestra institución desde que se estableció el sistema de información.

Resultados. El porcentaje de donantes altruistas a repetición aumentó a lo largo del tiempo a medida que el número de donantes de reemplazo que donaban sangre por primera vez se redujo en ambos sexos. La proporción de donantes altruistas subió de $20 \%$ de todos los donantes en 1995 a 57\% en 2001. En 2001, los donantes que donaban por primera vez representaban solamente $52 \%$ de todos los donantes de sangre, en comparación con $88 \%$ en 1995. La proporción de mujeres donantes subió de 20 a 37\% de todos los donantes en el período estudiado.

Conclusiones. Nuestros datos confirman que la población de São Paulo, Brasil, ha respondido bien a las estrategias de mercadeo que han sido adoptadas en nuestra institución. Consideramos que la adopción de iniciativas de promoción similares en otras partes del Brasil daría resultados positivos de igual naturaleza.

International Symposium on Advances in Transfusion Safety

\author{
Dates: $\quad 4-6$ June 2003 \\ Location: National Institutes of Health \\ Bethesda, Maryland, United States of America
}

The International Symposium on Advances in Transfusion Safety will highlight issues of concern in both developed and developing countries. The symposium will provide an overview of the "state of the art" in transfusion safety. The event is targeted to a professional audience in industry, government, and academia. The event will be held on the campus of the National Institutes of Health (NIH), which is located just outside of Washington, D.C. The sponsors of the meeting include the International Association for Biologicals (IABs), the Food and Drug Administration of the United States, the American Association of Blood Banks, and NIH's National Heart, Lung and Blood Institute.

The meeting will have 16 different technical sessions. Among the session topics are the current status of blood safety, new safety technologies, blood safety priorities in the developed and developing world, testing and inactivation, donor recruitment and selection, donor management in the developing world, product standardization, the movement toward international harmonization, and surveillance and management of medical errors.

The symposium registration fee is US\$ 500 for employees of government, academic, or other institutions that have an IABs membership, if paid before 1 May; after that date, the fee is US\$ 600 . For other persons the registration fees start at US\$ 600 if paid before 1 May and US\$ 700 after that date.

\title{
Information:
}

International Association for Biologicals

8, chemin de la Gravière

$\mathrm{CH}-1227$ Acacias-Geneva

Switzerland

Telephone: 41223011036 • Fax: 41223011037

E-mail: iabs@iabs.org

Internet: http://www.iabs.org 